УДК УДК 811.111’373.43

DOI: $10.15421 / 382002$

I. Bezrodnykh, O. Konopelkina

І. Г. Безродних, О. О. Конопелькіна

И. Г. Безродных, Е. А. Конопелькина

Oles Honchar Dnipro National University

Дніпровський начіональний університет імені Олеся Гончара

Днепровский национальный университет имени Олеся Гончара

\title{
POLITICAL METAPHOR AS A MEANS OF LINGUISTIC REPRESENTAION OF DONALD TRUMP'S IMAGE IN MASS MEDIA
}

\author{
ПОЛІТИЧНА МЕТАФОРА ЯК ЛІНГВІСТИЧНИЙ ЗАСІБ \\ РЕПРЕЗЕНТАЦІЇ ОБРАЗА ДОНАЛЬДА ТРАМПА В ЗМІ
}

\section{ПОЛИТИЧЕСКАЯ МЕТАФОРА КАК ЛИНГВИСТИЧЕСКИЙ ПРИЁМ РЕПРЕЗЕНТАЦИИ ОБРАЗА ДОНАЛЬДА ТРАМПА В СМИ}

The article under discussion has focused on the peculiarities the conceptual metaphor usage in the speeches of the 45th and current president of the United States Donald Trump. The topicality of the investigation is predetermined by the steady increase of professional interest of political discourse participants, mass media in particular, in the choice of effective instruments of political and ideological relations coverage with a simultaneous public request for quality of the politically directed content. The differentiation of political metaphor features and its functions in publicistic discourse is essential for the exploration of efficient linguistic means of impact on the political mediatext audience. Grounding on the empiric material analysis (leading English-language mass media) the linguistic factors of the leader of a democratic country political image formation have been considered. The characteristics of the use of metaphor as a multilingual means of a politician mass media image formation based on the contemporary mass media have been outlined. The article suggests a complex study of the use of political metaphor in the texts of English-language mass media with the emphasis on the leading tendencies of the political utterance metaphorization within the framework of the contemporary political discourse. The major types of conceptual metaphor, facilitating the political image formation, have been studied.

Keywords: metaphor, conceptual metaphor, political discourse, political speeches, mass media language.

У статті основну увагу приділено особливостям використання концептуальної метафори у виступах 45-го президента США Дональда Трампа. Актуальність дослідження зумовлена неухильним зростанням професійного інтересу учасників політичного дискурсу, зокрема засобів масової інформації, до вибору ефективних інструментів висвітлення політичних та ідеологічних відносин з одночасним публічним запитом на якість політично спрямованого контенту. Диференціація ознак політичної метафори та їі функцій у публіцистичному дискурсі є суттєвою для дослідження ефективних мовних засобів впливу на аудиторію політичного медіатексту. Грунтуючись на емпіричному аналізі матеріалів (провідних англомовних 3МI), розглянуто лінгвістичні фактори формування політичного іміджу лідера демократичної країни. Викладено характеристики

(C) Bezrodnykh I. , Konopelkina O., 2020 
використання метафори як багатомовного засобу формування іміджу політика у ЗМI на основі сучасних засобів масової інформації. Запропоновано комплексне дослідження використання політичної метафори в текстах англомовних засобів масової інформації 3 акцентом на провідні тенденції метафоризації політичного висловлювання в рамках сучасного політичного дискурсу. Основні типи концептуальних метафор, що сприяють політичному формуванню іміджу, були розглянуті та дослідженні.

Ключові слова: метафора, концептуальна метафора, політичний дискурс, політичні виступи, мова засобів масової інформації.

Обсуждаемая статья сосредоточена на особенностях использования концептуальной метафоры в выступлениях 45-го президента США Дональда Трампа. Актуальность исследования предопределена неуклонным ростом профессионального интереса участников политического дискурса, в частности СМИ, к выбору эффективных инструментов освещения политических и идеологических отношений с одновременным общественным запросом на качество политически направленного контента. Разграничение характеристик политической метафоры и ее функций в публицистическом дискурсе имеет важное значение для исследования эффективных языковых средств воздействия на аудиторию политического медиатекста. На основе анализа эмпирического материала (ведущих англоязычных СМИ) рассмотрены лингвистические факторы формирования политического имиджа лидера демократической страны. Обозначены особенности использования метафоры как многоязычного средства формирования имиджа политика в СМИ. В статье предложено комплексное исследование использования политической метафоры в текстах англоязычных СМИ с акцентом на ведущие тенденции метафоризации политического высказывания в рамках современного политического дискурса. Основные типы концептуальных метафор, облегчающих политическое формирование имиджа, были рассмотрены.

Ключевые слова: метафора, концептуальная метафора, политический дискурс, политические выступления, язык СМИ.

Nowadays metaphorical vocabulary should be regarded as a powerful instrument of influence on human consciousness as well as a tool of public opinion formation, besides it effectively promotes the economy of language resources through the high informativity and bright emotional connotation, which makes it an efficient and widely used means of two basic functions of publicistic style realisation: informative and that of influence. As the publicism is to efficiently form public opinion and on the whole to crucially intervene into public life, it seems inappropriate to use inexpressive statements in the mass media discourse. At the same time, choosing figurative expression of ideas and metaphorical vocabulary, the author of political content must realize whether their message will be adequately perceived by various groups of addressees, whether the statement can be regarded as the reflection of the outworld realities, whether it appeals to the readership, taking into account their own worldviews. Thus, the metaphor in newspaper style is first of all to reflect the real world and objective knowledge of it, which is stated in the language with the help of emotionally coloured and comprehensible by association vocabulary. In addition, a metaphor can be regarded as a means of a participant of political discourse personal conceptual thinking, such being the case; we should treat it as an author's metaphorical utterance.

It is of prior importance to identify the features of political metaphor and its functions within the framework of publicistic discourse in order to determine the efficient linguistic means of impact on the political mediatext audience, as well as to study the current transformations in the sphere of political thinking and expression. The linguistic analysis of the stated language phenomenon allows us to identify trends related to lexical and semantic processes in the field of political speech, as well as key features of new words and expressions formation in the contemporary Englishlanguage media space. The 
study of current language trends involved in the metaphorization of journalistic texts, potentially contributes to the rise of political metaphor efficiency due to the fact that the language of media is a bright reflection of the current state and trends of not only language development but that of society as a whole, besides it significantly influences public opinion and serves as a means of generating it. It should be noted that nowadays political metaphor is to be considered not only as one of the most widely used means of politicians' image cultivation but also as an effective tool of PR-technologies, besides, as it has already been stated, it is an essential constituent of political mediatexts linguistic and semantic expressiveness.

George Lakoff and Mark Johnson, whose theory of conceptual metaphor is considered to be fundamental in the English-language linguistic tradition, regard metaphor as a projection of knowledge about the source sphere onto the sphere which is being coped with. The result is certain peculiar manifestations of this conceptual projection (so-called sub projections). The researchers emphasize that the concept of metaphor is a general notion rather than linguistic one; it is a thought tool and can function in all the spheres of human activity [1, c.393].

The object of the article under consideration is political metaphor as a means of image cultivation in the texts of contemporary English-language print media. The subject of the research is the linguistic features of the metaphor usage in the texts of Donald Trump's speeches. The aim of the study is to clarify the linguistic nature of the conceptual metaphor performance in the contemporary political media discourse as well as its role in the politician's image cultivation and promotion in mass media.

Current President Donald Trump won presidency as a Republican in 2016 and entered upon the office in January 2017. The inauguration of the 45th president was accompanied by numerous protests, but a considerable part of population did support Trump during the election campaign and can be said to be still setting their hopes upon this politician.

It should be noted that Donald Trump's media image remained controversial and scandalous for many years, long before his decision to take part in the election, though it is the fact that the actions and speeches of the future president were characterized by certain consistency, which was probably one of the keys to his victory.

The English-language world media widely covered both the course of the American election campaign and the first steps of the newly elected president, focusing on Donald Trump's statements, including the language means he preferred. In addition, the American leader's political career has repeatedly been the subject of jokes and bright evaluative statements and has generated many linguistic and graphic «memes», which can be considered one of the signs of deep interest of political media in the personality and media image of the US president.

Therefore, taking into consideration everything mentioned above, it is seems relevant to carry out the analysis of the practical use of conceptual metaphor in the process of Donald Trump's image cultivation as exemplified in the headlines and texts of such leading English-language media as The New Yorker, The Washington Post, The New York Times, New Statesman, Los Angeles Times, The Globe and Mail, The Daily Mail.

It is worth emphasizing that the core idea of Donald Trump's political program from the very beginning of his promotion as a presidential candidate, and later - the slogan of the entire election campaign has become the phrase «Make America Great Again». This utterance was borrowed from the election rhetoric of former US President Ronald Reagan, during whose presidency, according to Trump, the country was in a better political position. The future president insisted that his country had lost its position on the world 
stage, and stressed the need for change, despite the cost of such changes. His sharpness and black-and-white mentality drove some Americans away from him, but Trump and his team managed to convince a large proportion of fellow citizens, who regarded such a leader as both the possibility to bring back the «glory days» of America and the key to quality changes, especially in the spheres of economy and social policy, leading to prosperous future of the country.

Donald Trump, for decades having been regarded as a talented and smart American businessman, economist and leader, scandalous to an extent but at the same time courageous and determined person, seemed to be the leader most Americans had expected for. The future president set out his own views on the problems of modern America in the book with metaphorical title «Crippled America: How to Make

America Great Again» (subspheres «Human Body» and «Medicine», frames «Body Structure» and «Disease»), where he used bright anthropomorphic metaphorical model. The attribute «crippled», in relation to the country suffering from a number of internal and external problems, evokes associations with a sick or disabled person. This metaphor allows the author to simultaneously appeal to feelings of both pity (the country is a suffering living being) and shame (because no citizen wants to see their country weak, «sick» and humiliated). In addition, the reader, especially patriotic one, will identify the country's suffering with their own, and will prefer to help America as if helping them, which helps to demonstrate the broad potential of anthropomorphic metaphor as a means of emotions wakening in the contemporary political discourse.

The metaphorical statement «Let's make America great again» (subsphere «Man as a person», frames «Emotions and feelings», «Social status») is anthropomorphic itself - as Trump speaks of the country as of a person, and the average American can feel that it has to do with every citizen, «there is still a hope», it is not too late to rectify wrongdoings and return to former greatness.

The newly elected president used an anthropomorphic metaphor in his inaugural speech, personifying America again, and at the same time identifying the whole country with all together and every individual citizen:

"Do not allow anyone to tell you that it cannot be done. No challenge can match the heart and fight and spirit of America. We will not fail» [5] - subsphere «Human body», frame - «Internal structure of the organism». It should be noted that the sociomorphic metaphorical models are also to be found in the statement, in particular the subsphere «War», frames - «War» («battle») and «Result of war» («fail»), as well as the subsphere «Social Institutions», the frame - «Religion» («Spirit,» soul «).

Thus it is obvious that the speaker identifies the country with a worthy, courageous man who fights «with all his heart and soul, and will not lose». This metaphorical statement is aimed at awakening the patriotic spirit of the audience, maintaining the high spirits and readiness for change and struggle.

It should be stated that sociomorphic metaphor is a common means of expressive linguistic representation of bodies of government, as it leads to clear associative flow in the mind of the recipient, generates predictable emotions and reactions of the latter. During his inaugural speech the newly elected President of the United States stated:

«January 20th 2017, will be remembered as the day the people became the rulers of this nation again» [5] - sunsphere - «Social status», frame - «Ruling elite».

Thus, Trump emphasizes that he is holding the presidency to turn the ordinary Americans into «rulers», «rulers» of the nation and the country. At the same time, he reminds of the importance of the correct distribution of «social roles»: 
"At the centre of this movement is a crucial conviction: that a nation exists to serve its citizens» [5] - subsphere - «Social position», frame - «Subordinates».

Here Trump insists on the idea that the country and the nation should «serve» the citizens, not the other way round, saying that it is a «key, crucial statement», his political program is based on. Using the sociomorphic metaphorical model of «Power», he states:

«From this day forward, a new vision will govern our land» [5] - subsphere - «Social position», frame - «Ruling elite».

The sociomorphic metaphor is to be found in the late speeches of the President of the United States, often used in the harsh and shocking statements of his. For example, when discussing the problematic situation in trade relations with China, Donald Trump compared the country's attitude to the United States with «rape»:

"We can't continue to allow China to rape our country, and that's what they're doing» (The Guardian) [2] - subsphere - «Criminal world», frame -»Crime».

Speaking at the rally of a pension community in Florida, Trump attacked the health policies of the Democratic Party candidates in the 2020 presidential race, and promised that as long as he remains the president, «no one will lay hands on your healthcare benefits «:

"No one will lay a hand on your Medicare benefits» (The New York Times) [9] subsphere - «Criminal World», frame - «Crime».

The expression «lay a hand « here means «steal», «pocket»; Donald Trump continues to draw this analogy, saying that the US health care system is «under threat», but he will not allow politicians to «steal» it and «give it away» to foreigners:

"Medicare is under threat like never before. I will never allow these politicians to steal your health care and give it away to illegal aliens» (The New York Times) [9] subsphere $-\gg$ Criminal world», frames $-\langle$ Threat», «Crime».

In the inaugural speech of the newly elected president, we find several striking examples of the use of nature-morphic metaphors. For example, speaking of the privileged position of a privileged minority in power, while most Americans suffer from poverty and systemic unresolved issues, Trump notes:

«For too long, a small group in our nation's Capital has reaped the rewards of government while the people have borne the cost» [5] - subsphere - «Plants», frames «The life cycle of plants», «Human economic activities».

In this case, the President accuses a small group of people in power, who, in his opinion, «gather the entire harvest,» but ordinary citizens have to pay for it, and develops his opinion with the statement:

«Washington flourished - but the people did not share in its wealth» [5] - subsphere «Plants», frames - «Life cycle of a plant», «Part of a plant».

Donald Trump draws the recipients' attention to the fact that Washington, as the personification of power structures, «thrives,» «prospers,» but this prosperity does not extend to the common people.

Nature-morphic metaphors can also be found on Twitter of the Head of the US. In particular, speaking about the difficult situation around the increase of illegal immigrants in the United States, he notes:

«Democrats are the problem. They don't care about crime and want illegal immigrants, no matter how bad they may be, to pour into and infest our Country, like MS-13. They can't win on their terrible policies, so they view them as potential voters! "(The New York Times) [8]. 
Trump uses the metaphor of the nature-morphic row «to pour into», which symbolizes the uncontrollability of the process of «inflow» of illegal immigrants, just as you cannot stop a river or a water flood (subsphere - «Force of nature $\ll$, frame $-\ll$ Flood $\ll$ ).

The politician metaphorically mentions the waters in his address to the nation about the increase of illegal drug trafficking on the southern borders, emphasizing that the heroin «flood» is coming to America from the south:

«Every week 300 of our citizens are killed by heroin alone, 90 percent of which floods across from our southern border» (The Washington Post) [4] - subsphere - «Force of nature», frame - «Natural disasters».

The inaugural speech of Donald Trump contains an example of a gloomy and sinister artefact metaphor of «tombstones», aimed at arising anxiety and sadness in people's hearts:

«... rusted-out factories scattered like tombstones across the landscape of our nation» [5] - subsphere - «Architecture», frame - «Buildings», subframe - «Cult buildings».

This statement also contains a bright pessimistic image of «rusty factories scattered throughout the country» - again, the politician applies the metaphorical depiction of destruction, in this case with the help of a collective artefact metaphor. Abandoned plants are compared to rusty waste, some small parts of the mechanism, carelessly scattered around (subsphere - «Mechanics», frame - «Part of the mechanism»).

Metaphorical means of Donald Trump's image cultivation in the Englishlanguage mass media. It should be noted that American and world English-language mass media were one of Donald Trump's main opponents during the election campaign of 2016. Not only pro-democratic media, but also relatively neutral mass media did not lose the chance to ridicule both the program of the future president and his personality.

The theatrical and circus metaphors (closely connected with the theme of lies) as well as the metaphors of war and destruction seem to be especially popular language tools to represent the image of Trump. For example, in The New Yorker, the author states:

"If you thought the first effort was the genuine one, you obviously haven't been watching closely these past two months, as Trump, like a silent-movie comic, has gone from calamity to calamity, each one more bruising than the last» (The New Yorker) [3].

The phrase "silent-movie comic», which is a sociomorphic metaphor for the «Performing Arts» subsphere of the «Cinema» frame, is aimed at demonstrating the dangerous helplessness of the president who, like a comedian, moves «from calamity to calamity», and each one is even more «destructive» («bruising») than the previous one.

The Washington Post made an even bolder comparison. In the title of the article, the newspaper called Trump «Frankenstein of the Republican Party»:

"Trump is the GOP's Frankenstein monster. Now he's strong enough to destroy the party» [7] - anthropomorphic metaphor, subsphere - «Human body», frame - «State of the body»; sociomorphic metaphor - «Linguistic art», frame - «Literature».

The Washington Post also notes that «Trump-era conservatism is a meaningless», twisted «caricature of true conservatism»:

"Trump-era 'conservatism' is twisted caricature of the real thing» [6] - sociomorphic metaphor - «Fine Arts», frame - «Fine Arts».

Turning to a nature-morphic metaphor, English-language mass media often use well-known expressions borrowed from works of culture. The popularity of the fantasy American series «Game of Thrones» contributed to the further spread in the media texts of the metaphorical comparison of «winter» with the coming dark and difficult times, most often in politics. The famous expression «Winter is coming» has been widely used: 
"'Winter is coming': Allies fear Trump isn't prepared for gathering legal storm» (The Washington Post) [10] - subsphere - «Natural forces and phenomena», frame - «Seasons».

Here the metaphor of «Natural Forces and Phenomena», frame - «Atmospheric Phenomena», namely - «storm» has been used as the personification of the concepts of «trouble», «fight», «great trouble» and so on.

Having analysed the use of political metaphor in the texts of popular mass we have come to the conclusion that nowadays one can witness a significant intensification of the process of metaphorization of socially meaningful texts and messages in general, and those politically oriented in particular, as the metaphor more than any other expressive linguistic means allows to fulfil the functions of political utterance. It should be noted that some of the titles or parts of the articles analysed within the framework of the given article are completely metaphorical, which can serve as the indicator of the high degree of metaphorization of mass media text.

\section{References}

1. Лакофф Джордж, Джонсон Марк. 6. Trump-era 'conservatism' is twisted Метафоры, которыми мы живем// Теория caricature of the real thing. URL: метафоры. Москва, 1990. 512 с.

https://www.washingtonpost.com/

2. Here are the reasons for Trump's economic 7. Trump is the GOP's Frankenstein monster. war with China. URL: https://www. theguardian.com/usnews/2019/aug/23/ trump-china-economic-war-why-reasons Now he's strong enough to destroy the party. URL: https://www.washingtonpost.com/

3. Is Donald Trump Losing It? URL: https://www.newyorker.com/news/johncassidy/is-donald-trump-losing-it

8. Trump's Rhetoric and Conservative Denial. URL: https://www.nytimes. com/2019/08/08/opinion/trump-el-pasoshootingnationalism.html

4. Most imported heroin comes through 9. Trump Uses Health Care Announcement legal points of entry. URL: https://www. washingtonpost.com/

5. The Inaugural Address. URL: https://www. whitehouse.gov/briefings-statements/theinaugural-address/ to Brand Democrats as Socialists. URL: https://www.nytimes.com/2019/10/03/us/ politics/medicare-executive-order.html

10. Winter is coming': Allies fear Trump isn't prepared for gathering legal storm. URL: https://www.washingtonpost.com

Надійшла до редакиї 20.10.2019 